\title{
RADIOCARBON-DATED VEGETAL REMAINS FROM THE CAVE ICE DEPOSITS OF VELEBIT MT., CROATIA
}

Z Kern $^{1,2 *}$, N Bočić ${ }^{3}$, Gy Sipos ${ }^{4}$

1. Institute for Geological and Geochemical Research, Research Centre for Astronomy and Earth Sciences, MTA, Budaörsi út 45, Budapest, H-1112, Hungary

2. Isotope Climatology and Environmental Research Centre (ICER), MTA ATOMKI, Bem tér 18/c, Debrecen, Hungary

3. University of Zagreb, Faculty of Science, Department of Geography, Marulićev trg 19/II Zagreb, 10000, Croatia

4. University of Szeged, Department of Physical Geography and Geoinformatics, Geochronology Research Group, Egyetem utca 2-6, Szeged, H-6722, Hungary

Correspondence to: Zoltán Kern; e-mail: kern@geochem.hu

ABSTRACT. Organic material and a few trunks have been recovered from the shrinking ice deposits of Velebit Mt., Croatia. Ten radiocarbon $\left({ }^{14} \mathrm{C}\right)$ data, seven new measurements and three recalibrated ones, from three cave ice deposits were evaluated. The new data argue for the preservation of a $\sim 1000$ yr-old deposit in the Kugina Ice Cave, and a $<500$ yr-old accumulation in the Ledena Pit. A radiocarbon age suggests that the ice in the lower section of Vukušić cave ice deposit is very likely older than 3500 yrs. The work is in progress to verify this suggestion. Evaluation of the temporal distribution of the calibrated ages of the ${ }^{14} \mathrm{C}$-dated vegetal remains allowed constraining the accumulation and ablation history of cave ice in the northern and central Velebit. Periods lacking vegetal remains in these cave ice deposits (before the $11^{\text {th }}$ century and in the $15^{\text {th }}$ century) tend to match with similar patterns from other cave ice deposits from the Eastern Alps and the Swiss Jura Mts, suggesting large-scale coherence regulating European cave ice mass balance changes over the past $\sim 1200$ years.

KEYWORDS: cave ice, ice accumulation gaps, speleology, Holocene, Dinarides, Velebit Mt.

\section{INTRODUCTION}

Cryospheric processes in karst systems are heavily under-researched, despite evidence of a rather dramatic ice loss documented in glaciated caves worldwide (Kern and Perşoiu 2013). A prominent karst region is SE Europe where numerous cavities host perennial ice and snow accumulations (Barović et al. 2018; Buzjak et al. 2018; Pennos et al. 2018; Temovski 2018; Nešić and Ćalić 2018). However, only very few data are available on the age of the cave ice deposits of this region (Horvatinčić 1996; Paar et al. 2013; Staut et al. 2016). 
Radiocarbon $\left({ }^{14} \mathrm{C}, \mathrm{t}_{1 / 2}=5730 \mathrm{yr}\right)$ is the primary dating tool for organic macroremains from cave ice sequences deposited before the $20^{\text {th }}$ century (Kern 2018). Vegetal macroremains have been analyzed frequently (e.g. Fórizs et al. 2004; Sancho et al. 2012; Spötl et al. 2014; Munroe et al. 2018; Perşoiu et al. 2017), and occasionally animal remains (Citterio et al. 2005; Hercman et al. 2010; Yonge and MacDonald 1999; Gradziński et al. 2016) have also been dated with the aim of placing constraints on the age of cave ice deposits.

Macroscopic organic remains could be situated in distinct stratigraphical positions within a cave ice sequence complicating the interpretation of a radiocarbon age depending on the stratigraphical context of the sample. Isolated individual objects found in otherwise organic-free ice layers might indicate rapid embedding in firn and ice representing positive cave ice balance (e.g. Spötl et al., 2014, Hercman et al. 2010, Gradziński et al. 2016). Organic inclusions concentrated along discrete layers are frequently observed in cave ice deposits. If these organic horizons occur parallel or sub-parallel in more-or-less regular spacing throughout the section they likely mark seasonal ablation periods, hence annual layering (see e.g. Munroe et al. 2018). However, if these intercalated layers of organic detritus form unconformities or unusually thick layers within the given cave ice sequence then they can be interpreted as stratigraphic markers of elongated (multiannual) negative mass balance periods (e.g. Stoffel et al. 2009; Spötl et al. 2014; Sancho et al. 2018) while ice layers represent positive mass balance periods in the accumulation history of cave ice.

Only limited research has been carried out on Croatian cave ice deposits so far (Buzjak et al. 2018), although mass ice loss (Kern et al. 2008; Bočić et al. 2014) or complete deglaciation (Bočić et al. 2012) have also been reported from these ice caves. Velebit Mt., represent a prominent range of the Dinaric Karst with the abundant occurrence of cave ice (Buzjak et al. 2018; Bočić et al. 2014).

Many horizons rich in organic material and a few individual trunks have been recovered from the shrinking ice deposits in the Velebit Mt.

Here we report seven new measurements and three earlier (recalibrated) data from Velebit Mt. One main purpose of the study is the comparison of the inferred geochronological data with those from cave ice deposits in other parts of Europe.

\section{SAMPLES AND METHODS}

The study area includes the northern and central parts of the Velebit mountain range (Figure 1) with a maximum altitude of $1699 \mathrm{~m}$ asl (the peak of Mali Rajinac). Mean annual air temperature in the area up to $1000 \mathrm{~m}$ asl is $\sim 5.5^{\circ} \mathrm{C}$, while in the highest region it drops to $3.5^{\circ} \mathrm{C}$. The coldest months are January and February (between -2 and $-5^{\circ} \mathrm{C}$ ) and the warmest one is July $\left(12-16^{\circ} \mathrm{C}\right)$. Annual precipitation in the northern and central part of the Velebit Mt. is up to $3000 \mathrm{~mm} / \mathrm{y}$. Snow can be present from the middle of November until the middle of May. Snow cover $\geq 30 \mathrm{~cm}$ can be expected in $36 \%$ of the year, and in $31 \%$ of days the 
snowpack is thicker than $50 \mathrm{~cm}$. Above $1500 \mathrm{~m}$ asl a humid boreal climate (Köppen's type Df) dominates and the lower parts have a temperate humid climate $(\mathrm{Cfb})$ mainly determined by the relief (Zaninović, 2008). Cooler conditions at higher elevations and strong temperature inversions in large depressions favor the accumulation of ice and snow in karst depressions such as deep mountain dolines, caves and pits (Buzjak et al. 2014, 2018).

Currently 230 ice and snow caves (predominantly shafts) are known in the Velebit Mt. (Buzjak et al. 2018). The spatial density of ice caves is highest in the area of northern Velebit Mt. (up to 25 ice caves $/ \mathrm{km}^{2}$ ).

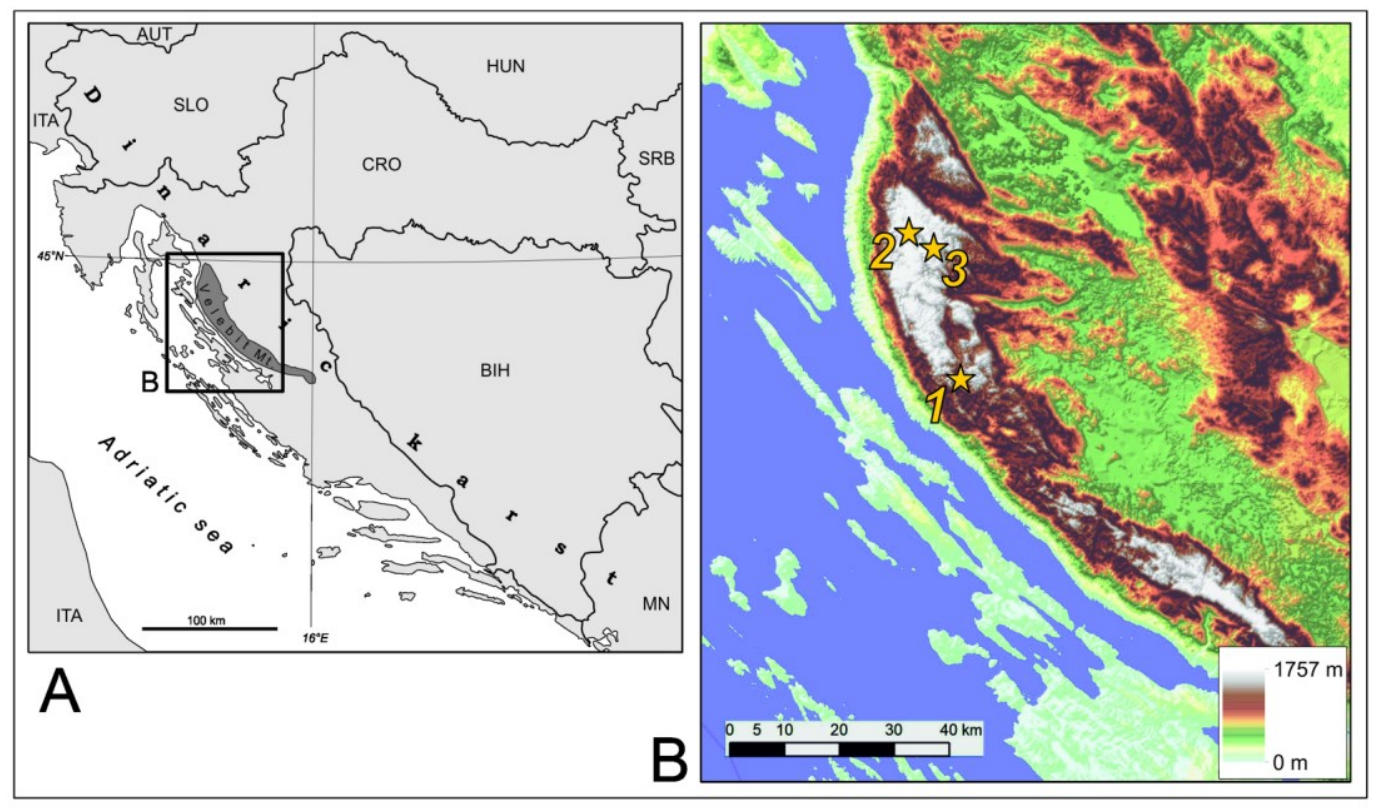

Figure 1 Location of the studied ice caves. A - Location of the Velebit Mt. in the Dinaric karst. The area enlarged in panel B is indicated (rectangle), B: Location of Kugina Ice Cave (1), Vukušić Ice Cave (2), and Ledena Pit (3)

\section{Caves and samples}

Kugina Ice Cave (Kugina ledenica, $44.61^{\circ} \mathrm{N}, 15.08^{\circ} \mathrm{E}, 1140 \mathrm{~m}$ asl) was explored in late July 2004 (Bočić 2005). The entrance opens in a forested area dominated by European beech (Fagus sylvatica L.). It is a simple cave with a single large entrance $(43 \times 27 \mathrm{~m})$ and a large chamber hosting a $15 \mathrm{~m}$-wide ice plug at the bottom (Figure 2a). With regard to its morphological characteristics, it is a typical static cave with firn. The known depth of the ice profile is about $20 \mathrm{~m}$. In 2004 the ice plug extended from a depth of $\sim 40 \mathrm{~m}$ to $61 \mathrm{~m}$, and the estimated ice volume was approximately $1500 \mathrm{~m}^{3}$. A peculiar feature of this deposit is the high number of wood trunks embedded in the ice (Bočić et al. 2014). 


\section{a KUGINAICE CAVE}
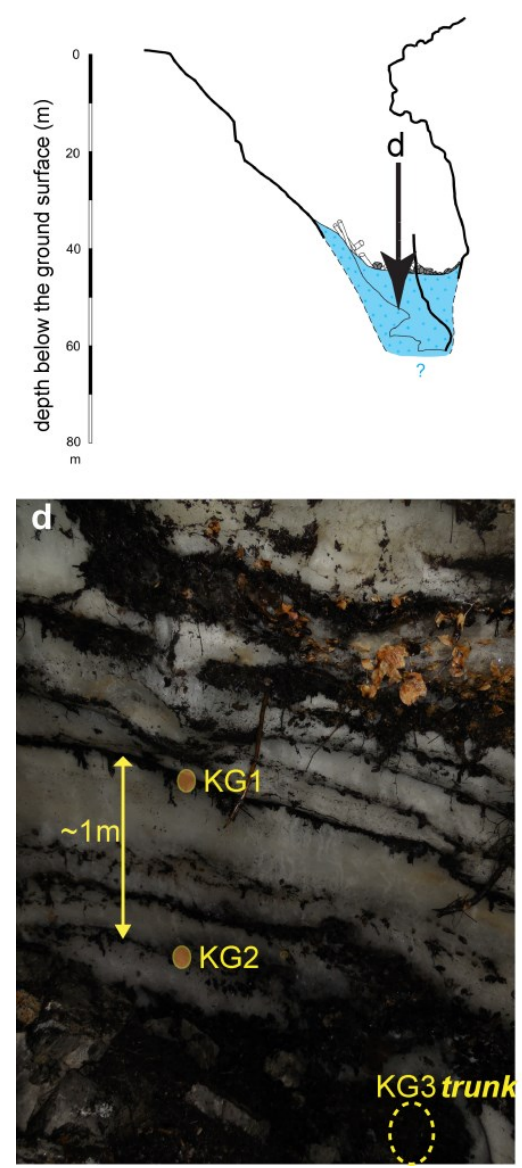

b VUKUŠIĆ ICE CAVE
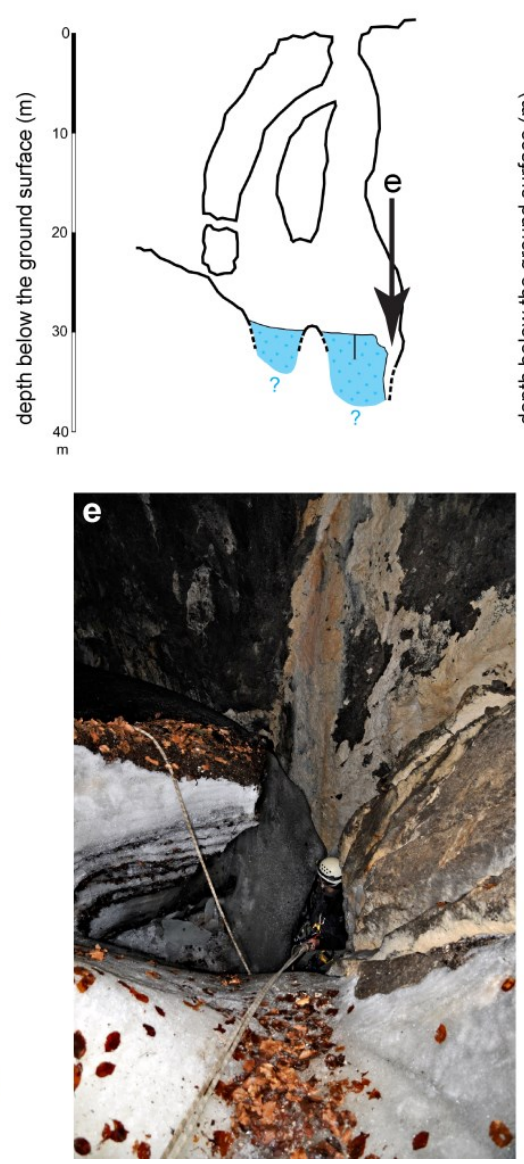

c LEDENAPIT

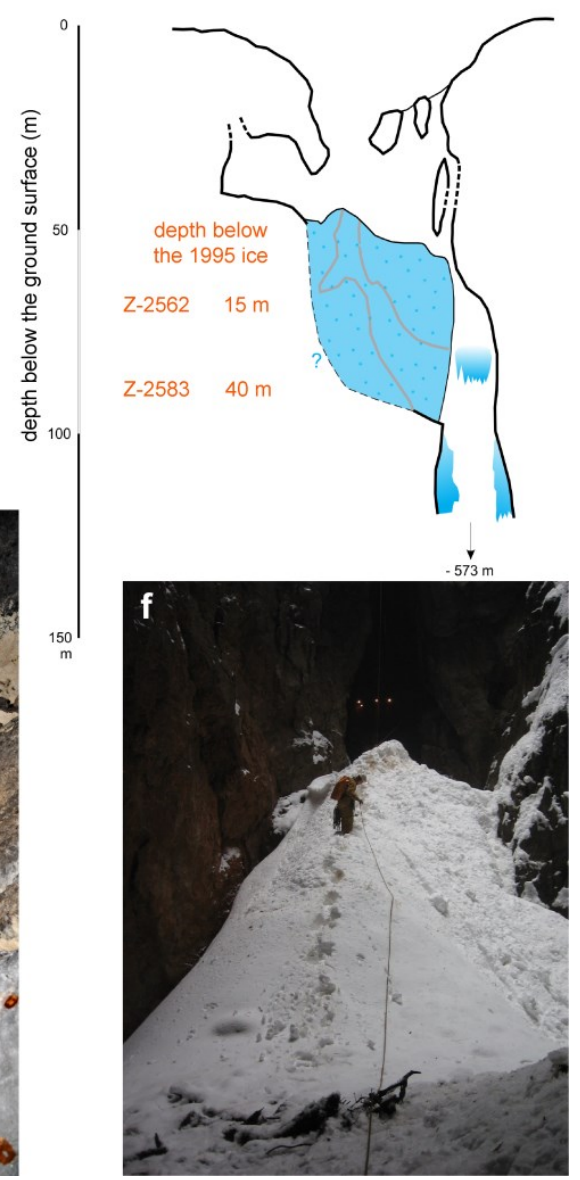

Figure 2 Cross sections and site photos of the studied ice caves. a: Kugina Ice Cave (after Bočić 2005). The location of the profile shown in panel $d$ is marked. b: Vukušić Ice Cave (redrawn after Kuhta 2002). Position of the image shown in panel e is marked. c: Ledena Pit (after Jelinić et al. 2001). d: Stratigraphy and location of the radiocarbon dated vegetal samples in Kugina Ice Cave. e: Accessible part of the ice cliff in Vukušić Ice Cave. f: Firn cone of the Ledena Pit.

Leaf remains (including 10-20 leaves of European beech) were collected from two major organic-rich horizons in the accessible lower section of the ice cliff during a survey in 2014 . Sample KG2 was collected close to the base of the ice cliff and KG1 1 m above KG2 (Figure 2d). However, the exact depth below the ice surface could not be measured because the sloping upper edge of the ice profile lacked a sharp delineation and the refreezing of surface ice layers over the edge. Another major and one minor organic horizon were also observed between these sampled layers, KG1 and KG2, and additional horizons rich in organic material were observed in higher sections of the ice cliff (Figure 2d). These horizons represent hiatuses in cave ice accumulation.

In addition, two pieces of relict tree trunks (KG3, KG4) found at the base of the ice deposit were also collected. Their outermost part was sampled and subjected to radiocarbon analysis 
in order to minimize the contribution of old wood and to constrain the date of their death and of subsequent burial to the cave ice.

Vukušić Ice Cave (Vukušić snježnica, 44.80N, 14.98E, $1470 \mathrm{~m}$ asl) is located near to the Zavižan peak in the northern part of the Velebit Mt., $\sim 8 \mathrm{~km}$ from the Adriatic coast. The forest surrounding the cave entrance is dominated by European beech and silver fir (Abies alba Mill). Vukušić Ice Cave formed in Middle Jurassic limestone. This shallow (rock overburden $<10 \mathrm{~m}$ ) cave consists of an entrance and two chambers filled with permanent ice (Figure $2 \mathrm{~b}$ ). These chambers are connected to the upper entrance via a shaft. The length of the cave is 20 $\mathrm{m}$, and the depth, from the upper entrance to the ice level, is $30 \mathrm{~m}$. The ice-covered area was only $\sim 50 \mathrm{~m}^{2}$ in October 2007. The thickness of the ice body, however, exceeded $10 \mathrm{~m}$.

Ten layers rich in organic material were identified in the accessible lateral upper part of the ice deposit of the Vukušić Ice Cave in 2014. A disk sample was sawn from a medium-sized trunk (VUK10) accessed from the side wall of the ice block. Two smaller branches (VUK11, VUK12) were collected from the best developed $9^{\text {th }}$ horizon situated $\sim 1.3 \mathrm{~m}$ below the ice surface in August 2014 (Figure 2e). All wood samples were identified as European beech. The samples were subsampled for ${ }^{14} \mathrm{C}$ dating. A conventional radiocarbon date had already been reported for this ice deposit (Z-4329, Kern et al. 2010, Table 1). However the stratigraphic relation of Z-4329sample to the new set of samples could not be reconstructed due to the changes in the morphology of the ice body.

The Ledena Pit (Ledena jama u Lomskoj dulibi, 44.74N, 15.03E, $1235 \mathrm{~m}$ asl) is a knee-shaped, $536 \mathrm{~m}$ deep pit (Jelinić et al. 2001). Its entrance opens in the Lomska duliba glacial valley. Part of the entrance pit preserves a large ice body extending from a depth of 50 $\mathrm{m}$ down to $90 \mathrm{~m}$, and 20-30 $\mathrm{m}$ in diameter (Figure 2c, f). The firn and ice formed from snow and by freezing of percolating water (Buzjak et al. 2014). The deposit is layered and contains soil and rock particles, leaves, branches, and bones (Buzjak et al. 2014). During speleological explorations ice samples were collected for tritium analysis at nine levels and two wood branches were obtained from the side wall of the ice deposit at depths of 15 and $40 \mathrm{~m}$ below the ice surface and sampled for radiocarbon analysis in 1995 (Horvatinčić 1996). The maximum tritium activity $\left(2.8 \mathrm{~Bq} \mathrm{~L}^{-1}\right)$ was found in the sample collected $3 \mathrm{~m}$ below the surface. This peak was assigned to the mid-1960s maximum in atmospheric activity related to thermonuclear weapon tests. The estimated period of cave ice deposition, assuming a constant rate of ice accumulation was considered to be in agreement with ${ }^{14} \mathrm{C}$ ages of $450 \pm 100$ years (Horvatinčić 1996; Horvatinčić and Krajcar-Bronić 1998). Later, the tritium activity of the local precipitation was modeled and the ${ }^{3} \mathrm{H}$ activity of the 1995 ice samples was adjusted to the model results (Kern et al. 2008). This re-assessment placed the likely position of the 1963 reference horizon to $3.75 \mathrm{~m}$ below the 1995 surface. 


\section{Radiocarbon analysis, calibration and age-depth modeling}

Wood branches weighted 20-30 g, while the batch of leaf remains hardly weighed 2-3 g. Each sample was subjected to the standard AAA chemical treatment (Tans and Mook 1980). Samples were converted to benzene using an Atomkomplex Prylad-type benzene synthesis line (Skripkin and Kovaliukh 1998). $\mathrm{Li}_{2} \mathrm{C}_{2}$ was produced by vacuum pyrolysis in the presence of 5-10 $\mathrm{g}$ of $\mathrm{Li}$ and approximately $1 \mathrm{~g}$ of $\mathrm{MnO}_{2}$. In case of small samples pyrolysis was repeated two more times to maximize the output. $\mathrm{Li}_{2} \mathrm{C}_{2}$ was hydrolyzed then to acetylene and finally converted to benzene using a vanadium catalyst. Any remaining $\mathrm{H}_{2} \mathrm{O}$ and $\mathrm{Rn}$ were removed by freezing and selective sublimation of components. All procedures were performed under vacuum. Benzene output ranged from $0.3 \mathrm{~g}$ (leaves) to $1.5 \mathrm{~g}$ (branches).

LSC measurements were performed using a Quantulus $1220^{\mathrm{TM}}$ ultra low level beta spectrometer. Benzene samples were transferred into $1.5 \mathrm{ml}$ teflon vials (Skripkin and Buzinnyi 2017) and a scintillation cocktail (mixture of toluene, PPO and POPOP) was added. The net time of measurement per sample was at least $48 \mathrm{~h}$ to ensure good counting statistics. Spectra were processed using the Easy View software.

The published radiocarbon age (Z-4329) from Vukušić Ice Cave was measured using an LSC Quantulus 1220 employing the benzene synthesis method for sample preparation at the Laboratory for Low-level Radioactivities, Ruđer Bošković Institute (Horvatinčić et al. 2004), while data for two older samples (Z-2562 and Z-2583) from Ledena Pit were obtained by gas proportional counting (Horvatinčić and Krajcar-Bronić 1998).

Calibration of ${ }^{14} \mathrm{C}$ dates was performed using OxCal v.4.3.2 (Bronk Ramsey 2009) in conjunction with the IntCal13 (Reimer et al. 2013) dataset. Calibrated ages are reported with two standard deviations $(2 \sigma)$.

The previously published conventional dates from Ledena Pit were recalibrated. Age-depth modeling was performed using the P_Sequence function (Bronk Ramsey 2008), taking into consideration the stratigraphical position of the samples (i.e., 15 and $40 \mathrm{~m}$ depth) and constraining the model with the 1963 reference horizon at $3.75 \mathrm{~m}$ below the 1995 surface. In the case of samples KG1 and KG2, only the relative stratigraphical position could be used in Bayesian modeling; therefore the Sequence function (Bronk Ramsey 2008) was applied. The model was further constrained by assigning 1995 and 2004 to to the top of the section for the Ledena Pit and Kugina Ice Cave, respectively. The reason for this is that archive samples were collected in 1995 in the Ledena Pit (Horvatinčić 1996), while the ice surface in Kugina Ice Cave cannot be younger than this date since the deposit has shrunk drastically since 2004 (Bočić et al. 2014). 
Preprint of Kern, Z. Bočić, N., Sipos, Gy. (2018) Radiocarbon dated vegetal remains from the cave ice deposits of Velebit Mt., Croatia. RADIOCARBON 60: 1391-1402.

DOI:10.1017/RDC.2018.108

Table 1 Radiocarbon activity and calibration results of vegetal remains from three cave ice deposits in the Velebit Mt. (Croatia).

\begin{tabular}{|c|c|c|c|c|c|c|}
\hline Cave & $\begin{array}{l}\text { sample } \\
\text { code }^{\mathrm{a}}\end{array}$ & Lab code & $\begin{array}{l}{ }^{14} \mathrm{C} \text { age } \\
(\mathrm{BP})\end{array}$ & $\begin{array}{l}\text { calibrated } \\
\text { (cal AD/BC) }\end{array}$ & $\begin{array}{l}\text { modeled }^{\mathrm{b}} \\
(\mathrm{cal} \mathrm{AD} / \mathrm{BC})\end{array}$ & ref. \\
\hline \multirow{5}{*}{$\begin{array}{l}\stackrel{\vec{G}}{\Xi} \\
\stackrel{\overrightarrow{0}}{\Xi}\end{array}$} & KG1 & CSZ93 & $915 \pm 25$ & $\begin{array}{l}\text { 1032-1168AD } \\
(93.1 \%)\end{array}$ & $\begin{array}{l}1041-1170 \mathrm{~A} \\
\mathrm{D}(95.4 \%)\end{array}$ & \multirow{5}{*}{ 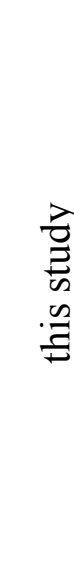 } \\
\hline & $\mathrm{KG} 2$ & CSZ94 & $935 \pm 25$ & $\begin{array}{l}\text { 1032-1156AD } \\
(95.4 \%)\end{array}$ & $\begin{array}{l}1030-1150 \mathrm{~A} \\
\mathrm{D}(95.4 \%)\end{array}$ & \\
\hline & KG3 & CSZ107 & $735 \pm 25$ & $\begin{array}{l}\text { 1226-1232AD (1.4\%) } \\
1244-1294 A D(94 \%)\end{array}$ & - & \\
\hline & KG4 & CSZ122 & $705 \pm 30$ & $\begin{array}{lr}1258-1306 & \text { AD } \\
(82.4 \%) & 1362-1385\end{array}$ & - & \\
\hline & & & & $\mathrm{AD}(13 \%)$ & & \\
\hline
\end{tabular}

modern

\begin{tabular}{|c|c|c|c|c|c|c|}
\hline \multirow{4}{*}{ 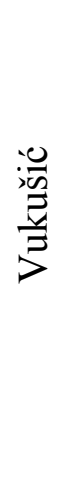 } & VUK10 & CSZ121 & $\begin{array}{l}(100.96 \pm 2.5 \\
2 \mathrm{pMC})\end{array}$ & & & \\
\hline & VUK11 & CSZ109 & $3245 \pm 30$ & $1610-1444 \mathrm{BC}(95.4 \%)$ & - & \\
\hline & VUK12 & CSZ110 & $330 \pm 30$ & $\begin{array}{l}\text { 1476-1642AD } \\
(95.4 \%)\end{array}$ & - & $\frac{2}{0}$ \\
\hline & & Z-4329 & $197 \pm 50$ & $\begin{array}{l}1638-1892 \mathrm{AD} \\
(78.1 \%) \\
1908 \mathrm{AD}<(17.3 \%)\end{array}$ & - & 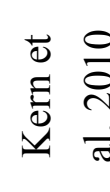 \\
\hline \multirow[b]{2}{*}{ 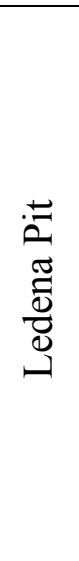 } & & Z-2562 & $150 \pm 100$ & $\begin{array}{l}1522-1575 \mathrm{AD}(4.4 \%) \\
1585-1590 \mathrm{AD}(0.3 \%) \\
1625 \mathrm{AD}<(90.7 \%)\end{array}$ & $\begin{array}{l}\text { 1832-1944A } \\
\mathrm{D}(95.4 \%)\end{array}$ & ๑ \\
\hline & & Z-2583 & $140 \pm 90$ & $\begin{array}{l}1528-1550 \mathrm{AD}(1.3 \%) \\
1634 \mathrm{AD}<(94.1 \%)\end{array}$ & $\begin{array}{l}1532-1554 \mathrm{~A} \\
\mathrm{D}(1.1 \%) \\
1561-1601 \mathrm{~A} \\
\mathrm{D}(2.1 \%) \\
1611-1854 \mathrm{~A} \\
\mathrm{D}(92.2 \%) \\
\end{array}$ & 壳 \\
\hline
\end{tabular}

a: only for the new samples

b: only where a depositional model could be established using a priori knowledge of the stratigraphical relationship between the samples

\section{RESULTS}


All but one of the samples provided historical ages (Table 1). The radiocarbon data indicate that the organic layers KG1 and KG2, observed in the lower section of the ice cliff in the Kugina Ice Cave, were deposited between AD 1041 and AD 1170 and between AD 1030 and AD 1150, respectively (Table 1). The trunk samples (KG3, KG4) yielded younger dates, indicating that the samples were very likely redeposited; they probably slided down during thawing and retreating of the ice wall (Bočić et al. 2014), and their collection spot at the foot of the ice cliff was not their original stratigraphical position. Since some additional ice layers were observed below the KG2 sample ( $\sim \mathrm{m}$, Figure $2 \mathrm{~b})$, the age of the basal ice deposit probably dates back to the turn of the $1^{\text {st }}$ to $2^{\text {nd }}$ millennium AD.

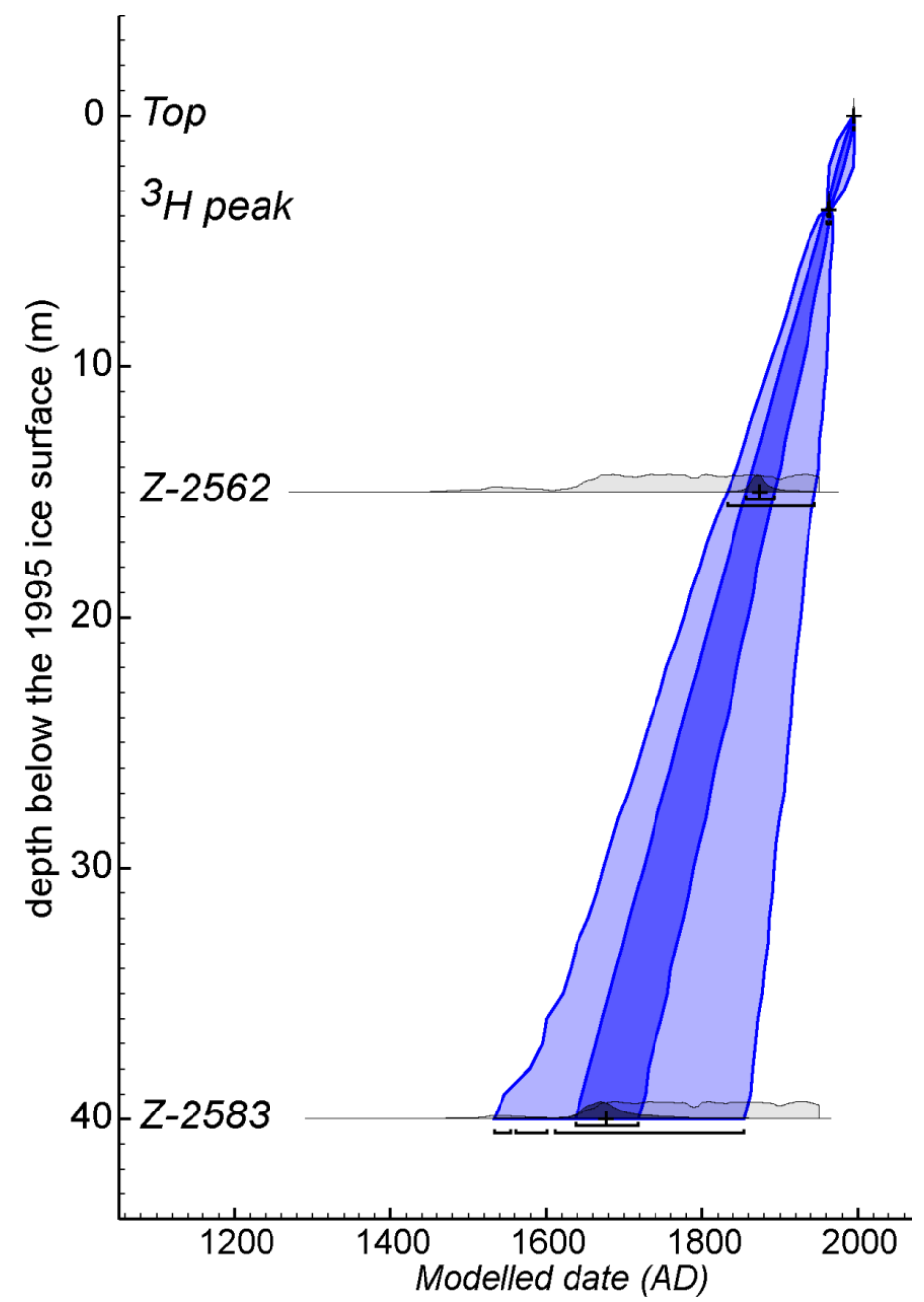

Figure 3 Depth-age model of the Ledena Pit. Light (dark) blue shading shows the $95 \%$ (68\%) confidence range of the Bayesian model. Original and modeled probability density distributions are plotted in light and dark grey, respectively.

Radiocarbon ages obtained for VUK11 and VUK12, which were collected from the best developed horizon with organic detritus in the accessible upper part of the Vukušić Ice Cave, 
showed a remarkable difference in age (Table 1) and probably bracket a major hiatus in the accumulation history of the cave ice between the $\sim 17^{\text {th }}$ century BC and the $\sim 16^{\text {th }}$ century AD. Bayesian age-depth modeling of the Ledena Pit using the recalibrated ${ }^{14} \mathrm{C}$ ages and taking into account the stratigraphical relation of the samples (Figure 3) suggests a younger age for the basal layer of the ice deposit (median date: 1680 AD, 95\% range: 1530-1860 AD) compared to the previous estimates (Horvatinčić 1996; Horvatinčić and Krajcar-Bronić 1998), although the error margins overlap.

\section{DISCUSSION}

\section{Age of the cave ice deposits of the Velebit Mt. in a Southern European context}

The new data reveal the preservation of ice as old as the mid-Holocene in the lower section of Vukušić cave ice deposit, and from Medieval times in Kugina Ice Cave. Geochronological information is scarce for other cave ice deposits in the Dinarides. Radiocarbon dating of wood samples collected in 2011 in a vertical passage at depths of $120 \mathrm{~m}$ and $160 \mathrm{~m}$ in another shaft system from the Velebit (Lukina jama-Trojama) showed an upper age of $410 \pm 75$ years (Paar et al. 2013). The same study assigned an age of $525 \pm 40$ years to another part of the Ledena Pit cave ice deposit based on the ${ }^{14} \mathrm{C}$ result of an individual piece of wood collected at a depth of $50 \mathrm{~m}$ in 2012 (Paar et al. 2013).

Comparing the radiocarbon data from the Velebit Mt. presented here with data from cave ice in Southern Europe also yields interesting results. Date of the basal layer of the Grotta de Castellato di Mezzo ice deposit (Dolomites, N Italy) was estimated to $1532 \pm 60 \mathrm{AD}$ according to counting of deposition bands whose annual nature was validated by tritium measurements in the upper $2.45 \mathrm{~m}$ of the ice block (Borsato et al., 2006). Dendrochronologically dated larch trunks collected from a thawing ice block at the entrance chamber of Ledena Jama pri Planini Viševnik (Slovenia) constrained the onset of cave ice deposition to $1703 \mathrm{AD}$ (Staut et al. 2016). Age constraints on cave ice deposits derived from ${ }^{14} \mathrm{C}$-dated vegetal remains are available for two major karstic regions of the Iberian Peninsula. Leafs and a branch collected from the ice deposits of the Altáiz and Verónica Ice Caves (Cantabrian Mts, Spain) were dated to the $17^{\text {th }}$ and $14^{\text {th }}$ century AD (Gómez-Lende 2015). Hitherto, the oldest cave ice layers in Southern Europe were identified in the A492 cave (Pyrenees, Spain), where calibrated ages ranged from 4256-4043 to 3637-3496 BC (Sancho et al. 2018) in the lower section of a $\sim 10$-m-thick firn/ice deposit (Belmonte-Ribas et al. 2014).

In the light of these data, the oldest layers of the ice block of the Kugina Ice Cave predate most of the previously studied cave ice occurrences in the Dinarides. Vukušić Ice Cave, however, hosts the oldest known cave ice deposit in the Central Mediterranean realm and the second oldest known cave ice deposit of the entire Mediterranean region. 


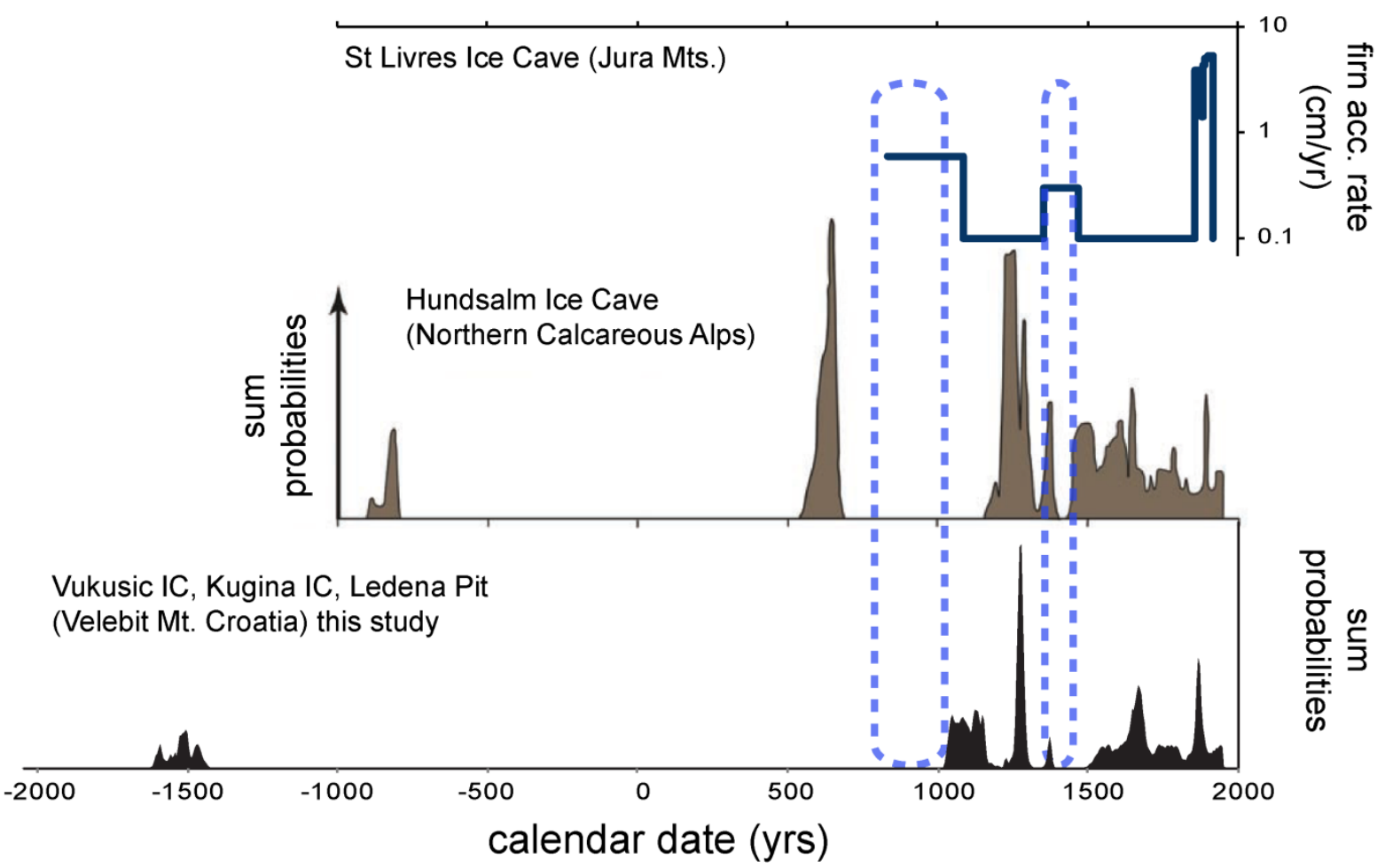

Figure 4 Sum probabilities of the calibrated and model-derived ages from cave ice deposits in the Velebit Mt. compared to a record from Hundsalm Ice Cave (Spötl et al. 2014) and the reconstructed firn accumulation rate of St. Livres Ice Cave (Stoffel et al. 2009). The dashed frames mark intervals with scarce organic deposition in the ice caves of Velebit and Northern Calcareous Alps and enhanced firn accumulation in the Jura.

\section{Comparison of mass balance periods in ice caves of the Velebit Mt. and other European} ice caves

The dated vegetal remains were collected from organic inclusions concentrated along discrete layers (Figure 2) or assumed to be released from similar stratigraphic position during the current thawing process of these deposits (such as KG3, KG4, VUK10). Therefore their age is preferred to be interpreted as indicative of times unfavorable of firn accumulation. The remarkable age difference of VUK11 and VUK12 clearly support the interpretation of the layers of concentrated organic inclusions as hiatus in the ice accumulation history of the Velebit cave ice deposits. Although, the age difference of VUK11 and VUK12, collected from the same erosion horizon, does not necessarily indicate a continuous negative mass balance over these c. 3000 years in the Vukušić Ice Cave. Organic horizons usually originate from a longer ablation period and are mixtures of both organics accumulated during the negative mass balance period and older material released by melting of older ice strata.

The probability densities of the calibrated and model-derived ages of the cave ice deposits of the Velebit Mt. appear to cluster into three periods spreading over the past 4000 years (Figure 4). The presence of concentrated organic material might indicate the timing of periods of 
negative mass balances, while periods of reduced or even lacking organic remains might indicate increased snow accumulation and positive mass balances.

Very few datasets are available from other cave ice deposits for comparison. The nearest available record is from a 7-m-thick deposit of snow, firn and congelation ice of the Hundsalm Ice Cave (Eastern Alps), where 19 radiocarbon data allowed to place constraints on the accumulation and ablation history of the cave ice (Spötl et al. 2014). For the 6-m-thick succession of the St. Livres Ice Cave (Swiss Jura Mts) the firn accumulation rate has been reconstructed based on 45 dendrochronologically and partly ${ }^{14} \mathrm{C}$-dated wood macrofossils for the past $\sim 1200$ years (Stoffel et al. 2009).

The periods lacking vegetal remains in the cave ice sequences of the Velebit match well with similar patterns from Hundsalm Ice Cave (Spötl et al. 2014) before the $11^{\text {th }}$ century and for the $15^{\text {th }}$ century $\mathrm{AD}$, and correspond to periods of higher cave firn accumulation rates reconstructed for St. Livres Ice Cave (Swiss Jura Mts) (Stoffel et al. 2009) (Figure 4). In addition, accumulation peaks of organic material also tend to correspond to periods of reduced cave firn accumulation rates in St. Livres Ice Cave and enhanced organic deposition in Hundsalm Ice Cave. Times of high abundances of ${ }^{14} \mathrm{C}$-dated vegetal remains of the Velebit ice deposits are preferably interpreted as indicative of times unfavorable of firn accumulation agrees well with the reduced firn accumulation rate in St. Livres Ice Cave. However, the interpretation of the observed corresponding pattern regarding the Hundsalm record is not straightforward because times of abundance peaks of ${ }^{14} \mathrm{C}$-dated wood remains have been interpreted as indicative of times favorable for rapid increased accumulation in the Hundsalm Ice Cave (Spötl et al. 2014).

Despite the contrast in the current interpretation of the of high abundances of ${ }^{14} \mathrm{C}$-dated vegetal remains the broad agreement suggests, at least, coherent changes in the mass balance of the cave ice deposits in the Dinaric and Alpine domains over the past $\sim 1200$ years. Since static ice caves, such like St Livres, Vukušić or Hundsalm Ice Cave, are sensitive recorders of winter precipitation and are relatively unaffected by summer conditions (Luetscher et al. 2005) presumably large-scale changes of winter precipitation patterns might be reflected in the spatiotemporal accordance/discordance of their mass balance fluctuations.

Firn accumulation rates calculated from a set of radiocarbon dates of organic layers of the Pyrenean A492 cave ice deposit (Sancho et al. 2018) overlap with the Velebit record only for the $1^{\text {st }}$ and $2^{\text {nd }}$ millennia $\mathrm{BC}$. There is some agreement between the higher Pyrenean firn accumulation rates reconstructed for the $12^{\text {th }}$ century $\mathrm{BC}$ and between $\sim 300 \mathrm{BC}$ and $60 \mathrm{AD}$ and periods lacking vegetal remains in the cave ice sequences of the Velebit. Vegetal remains are lacking for the latter period also in the Hundsalm Ice Cave (Figure 4). However, this comparison is cannot be conclusive since the date of the current surface of the ice body in the A294 cave was estimated to ca. 170 cal AD (Sancho et al. 2018) so there is practically no overlap with the better replicated last millennial period of the Velebit dataset. 


\section{CONCLUSIONS}

A set of ten radiocarbon data, including seven new measurements, are reported from three cave ice deposits of the Velebit Mt. The results show that two of the studied cave ice deposits preserve organic material older than previously documented in the Dinaric Karst. Radiocarbon age of a sample suggests that the ice in the lower section of Vukušić cave ice deposit is very likely older than 3500 yrs. The work is in progress to verify this suggestion. Maxima in the abundance of organic material (late- $13^{\text {th }}$ and late- $17^{\text {th }}$ century AD) and periods lacking vegetal remains ( $8^{\text {th }}$ and $15^{\text {th }}$ century AD) in cave ice sequences of the Velebit broadly match similar patterns reported from Hundsalm Ice Cave (Eastern Alps; Spötl et al. 2014) and St. Livres Ice Cave (Swiss Jura Mts; Stoffel et al. 2009) suggesting large-scale coherence in conditions regulating European cave ice mass balance changes over the past $\sim 1200$ years.

\section{ACKNOWLEDGEMENTS}

The research was supported by the European Union and the State of Hungary, co-financed by the European Regional Development Fund in the project of GINOP-2.3.2.-15-2016-00009 'ICER' and by the Hungarian Human Resource Development Operational Program (EFOP-3.6.2-16-2017-00010). LP2012-27/2012, UniZG 202799/2015, and HURO/1101/126/2.2.1. are also acknowledged for financial support. Thanks to Tomislav Rukavina and Josip Tomaić (Nature Park Velebit) and the Speleological Society Karlovac for their great help during field work. Enikő Lázár, Dávid Filyó and Tamás Bartyik (University of Szeged) are thanked for preparing and measuring the seven new radiocarbon samples. This is contribution No.62 of the $2 \mathrm{ka}$ Palæoclimatology Research Group.

\section{REFERENCES}

Barović G, Kicińska D, Mandić M, Mulaomerović J. 2018. Ice Caves in Montenegro and Bosnia and Herzegovina In: Persoiu, A. and Lauritzen, SE (eds) Ice Caves, Elsevier, 263-283.

Belmonte-Ribas A, Sancho C, Moreno A, Lopez-Martinez J, Bartolome M. 2014. Present-day environmental dynamics in ice cave A294, Central Pyrenees, Spain. GFDQ 37/2:131-40. DOI 10.4461/GFDQ.2014.37.12

Bočić N. 2005. Kugina ledenica na srednjem Velebitu. Speleosfera 2:54-8.

Bočić N, Faivre S, Kovačić M, Horvatinčić N. 2012. Cave development under the influence of Pleistocene glaciation in the Dinarides - an example from Štirovača Ice Cave (Velebit Mt., Croatia). Zeitschrift für Geomorphologie 56:409-33.

Bočić N, Buzjak N, Kern Z. 2014. Some new potential subterranean glaciation research sites from Velebit Mt. (Croatia) In: Land L, Kern Z, Maggi V, Turri S, editors. Proceedings of 
the Sixth International Workshop on Ice Caves, August 17-22, Idaho Falls, Idaho, USA: NCKRI Symposium 4. Carlsbad (NM): National Cave and Karst Research Institute, 72-76.

Borsato A, Miorandi R, Flora O. 2006. I depositi di ghiaccio ipogei della Grotta dello Specchio e del Castelletto di Mezzo (Dolomiti di Brenta, Trentino): morfologia, età ed evoluzione recente. Studi Trent. Sci. Nat., Acta Geol 81:53-74.

Bronk Ramsey C. 2009. Bayesian analysis of radiocarbon dates. Radiocarbon 51(1):337-60.

Bronk Ramsey C. 2008. Deposition models for chronological records. Quaternary Science Reviews 27:42-60.

Buzjak N, Bočić N, Paar D, Bakšić D, Dubovečak V. 2018. Ice Caves in Croatia. In: Perşoiu, A. and Lauritzen, SE (eds) Ice Caves, Elsevier, pp.335-369.

Buzjak N, Paar D, Dubovečak, V., Bočić, N. 2014. The influence of karst topography to ice cave occurrence - Example of Ledena Jama in Lomska Duliba (Croatia). In: Land L, Kern Z, Maggi V, Turri S, editors. Proceedings of the Sixth International Workshop on Ice Caves, August 17-22, Idaho Falls, Idaho, USA: NCKRI Symposium 4. Carlsbad (NM): National Cave and Karst Research Institute, 17-23.

Citterio M, Turri S, Perşoiu A, Bini A, Maggi V. 2005. Radiocarbon ages from two ice caves in the Italian Alps and the Romanian Carpathians and their significance. In: Mavlyudov B. editor. Glacier Caves and Glacial Karst in High Mountains and Polar Regions. Institute of geography of the Russian Academy of Sciences, Moscow, p. 87-92.

Fórizs I, Kern Z, Nagy B, Szántó Zs, Palcsu L, Molnár M. 2004. Environmental isotope study on perennial ice in the Focul Viu Ice Cave, Bihor Mts., Romania. Theoretical and Applied Karstology 17:61-9.

Gómez-Lende M. 2015. Las cuevas heladas en Picos de Europa: clima, morfologías y dinámicas, PhD Thesis. Universidad de Valladolid, 663pp.

Gradziński M, Hercman H, Peresviet-Soltan A, Zelinka J, Jelonek M. 2016. Radiocarbon dating of fossil bats from Dobšina Ice Cave (Slovakia) and potential palaeoclimatic implications. Annales Societatis Geologorum Poloniae 86:341-50. doi:10.14241/asgp.2016.016

Hercman H, Gąsiorowski M, Gradziński M, Kicińska D. 2010. The first dating of cave ice from the Tatra Mountains, Poland and its implication to palaeoclimate reconstructions. Geochronometria 36:31-8.

Horvatinčić N. 1996. Isotopic measurement in ice, Ledenica Cave, Velebit, Croatia. (In Croatian with English summary) In: Kubelka D, Kovač J, editors. Proceedings of the third symposium of the Croatian Radiation Protection Association, Zagreb p. 297-302.

Horvatinčić N, Krajcar-Bronić I. $1998 .{ }^{14} \mathrm{C}$ and ${ }^{3} \mathrm{H}$ as indicators of the environmental contamination. RMZ-Materials and Geoenvironment 45:56-60. 
Horvatinčić N, Barešic J, Krajcar Bronić I, Obelić B. 2004. Measurement of low ${ }^{14} \mathrm{C}$ activities in liquid scintillation counter in the Zagreb Radiocarbon Laboratory. Radiocarbon 46:10516.

Jelinić I, Horvatinčić N, Božić V. 2001. Ledena Jama (The Ice Pit) in Lomska Duliba. (in Croatian with English summary) Senjski zbornik 28:5-28

Kern Z. 2018. Dating cave ice deposits. In: Persoiu, A. and Lauritzen, SE (eds) Ice Caves, Elsevier, 109-122.

Kern Z, Perşoiu A. 2013. Cave ice - the imminent loss of untapped mid-latitude cryospheric palaeoenvironmental archives. Quaternary Science Reviews 67:1-7.

Kern Z, Bočić N, Horvatinčić N, Fórizs I, Nagy B, László P. 2008. Palaeoenvironmental records from ice caves of Velebit Mountains - Ledena Pit and Vukušić Ice Cave, Croatia. In: Kadebskaya O, Mavlyudov BR, Pyatunin M. editors. 3rd International Workshop on Ice Caves Proceedings, Kungur, p. 108-113.

Kern Z, Fórizs I, Horvatinčić N, Széles É, Bočić N, Nagy B. 2010. Glaciochemical investigations on the subterranean ice deposit of Vukušić Ice Cave, Velebit Mountain, Croatia. The Cryosphere Discussion 4:1561-91, doi:10.5194/tcd-4-1561-2010

Kuhta M. 2002. Inventarizacija speleoloških objekata na podruèju Nacionalnog parka "Sjeverni Velebit", Inventarisation of the speleological features in the area of the National park “Sjeverni Velebit”, Speleološki klub Željezničar, Speleological club Željezničar, Zagreb, $52 \mathrm{pp}$.

Luetscher M, Jeannin PY, Haeberli W. 2005. Ice caves as an indicator of winter cli-mate evolution - a case study from the Jura Mountains. Holocene 15:982-93.

Munroe JS, O'Keefe SS, Gorin AL. 2018. Chronology, stable isotopes, and glaciochemistry of perennial ice in Strickler Cavern, Idaho, USA. GSA Bulletin 130:175-92 DOI:10.1130/B31776.1

Nešić D, Ćalić J. 2018. Ice cave in Serbia. In: Perşoiu, A. and Lauritzen, SE (eds) Ice Caves, Elsevier, 611-624.

Paar D, Buzjak N, Sironić A, Horvatinčić N. 2013. Paleoklimatske arhive dubokih jama Velebita. In: Marjanac L., editor. Knjiga sažetaka 3. znan. skup Geologija kvaratara u Hrvatskoj; Zagreb, Croatia: HAZU. p. 39-40.

Pennos C, Styllas M, Sotiriadis Y, Vaxevanopoulos M 2018. Ice caves in Greece. In: Perşoiu, A. and Lauritzen, SE (eds) Ice Caves, Elsevier, 385-397.

Perșoiu A, Onac BP, Wynn JG, Blaauw M, Ionita M, Hansson M. 2017. Holocene winter climate variability in Central and Eastern Europe. Scientific Reports 7(1):1196

Reimer PJ, Bard E, Bayliss A, Beck JW, Blackwell PG, Bronk Ramsey C, Grootes PM, Guilderson TP, Haflidason H, Hajdas I, Hatte C, Heaton TJ, Hoffmann DL, Hogg AG, Hughen KA, Kaiser KF, Kromer B, Manning SW, Niu M, Reimer RW, Richards DA, Scott EM, Southon JR, Staff RA, Turney CSM, van der Plicht J, 2013. IntCal13 and 
Marine13 radiocarbon age calibration curves 0-50,000 years cal BP. Radiocarbon 55(4):1869-87.

Sancho C, Belmonte A, López-Martínez J, Moreno A, Bartolomé M, Calle M, Santolaria P. 2012. Potencial paleoclimático de la cueva helada A294 (Macizo de Cotiella, Pirineos, Huesca). Geogaceta 52:101-4.

Sancho C, Belmonte Á, Bartolomé M, Moreno A, Leunda M, López-Martínez J. 2018. Middle-to-late Holocene palaeoenvironmental reconstruction from the A294 ice-cave record (Central Pyrenees, northern Spain). Earth and Planetary Science Letters 484:135-44.

Skripkin VV, Kovaliukh NN. 1998. Recent developments in the procedures used at the SSCER Laboratory for the routine preparation of lithium carbide. Radiocarbon 40:211-4.

Skripkin VV, Buzynnyi MG. 2017. Teflon Vials For Precise C-14 in Benzene Measurements by LSC Technique. Biological and Chemical Research 4:229-33.

Spötl C, Reimer PJ, Luetscher M. 2014. Long-term mass balance of perennial firn and ice in an Alpine cave (Austria): Constraints from radiocarbon-dated wood fragments. The Holocene 24:165-75 doi: 10.1177/0959683613515729

Staut M, Vreča P, Merela M, Brenčič M. 2016. Recent fluctuations of ice deposits in the cave Ledena Jama pri Planini Viševnik, NW Slovenia. In: Mihevc A, Hajna Zupan N, Gostincar P (eds) 7th International Workshop on Ice Caves: Program Guide and Abstracts. Postojna, Karst Research Institute ZRC SAZU, pp. 73-74.

Stoffel M, Luetscher M, Bollschweiler M, Schlatter F. 2009. Evidence of NAO control on subsurface ice accumulation in a $1200 \mathrm{yr}$ old cave-ice sequence, St. Livres ice cave, Switzerland. Quaternary Research 72:16-26. DOI:10.1016/j.yqres.2009.03.002.

Tans PP, Mook WG. 1980. Past atmospheric $\mathrm{CO}_{2}$ levels and ${ }^{13} \mathrm{C} /{ }^{12} \mathrm{C}$ ratios in tree rings. Tellus 32:268-83.

Temovski M. 2018. Ice Caves in FYR of Macedonia. In: Persoiu, A. and Lauritzen, SE (eds) Ice Caves, Elsevier, pp.455-478.

Yonge CJ, MacDonald WD. 1999. The potential of perennial cave ice in isotope paleoclimatology. Boreas 28:357-62.

Zaninović K. editor. 2008. Klimatski atlas Hrvatske. Meteorological and Hydrological Service of Croatia, Zagreb 